\title{
Availability of barley straw application on oil spill clean up
}

\author{
${ }^{1}$ M. Husseien; ${ }^{2}$ A. A. Amer; ${ }^{3}$ A. El-Maghraby; ${ }^{4}$ N. A.Taha \\ ${ }^{1}$ Alexandria University, Faculty of Engineering, Chemical Department, Alexandria, Egypt \\ ${ }^{2}$ Alexandria Petroleum Company, Alexandria, Egypt \\ ${ }^{3}$ Department of Fabrication Technology, Institute of Advanced technology and New Materials, Mubarak City for \\ Scientific Research and Technology Applications, Alexandria, Egypt \\ ${ }^{4}$ Institute of Advanced Technology and New Materials, Mubarak City for Scientific Research and Technology \\ Applications, Alexandria, Egypt
}

Received 22 June 2008; $\quad$ revised 13 September 2008; accepted 26 November 2008; $\quad$ available online 10 December 2008

\begin{abstract}
Oil spills are a global concern due to the environmental and economical impact. Various commercial systems have been developed to control these spills, including the use of fibers as sorbents. However, most sorbents end up in landfills or in cineration after single use. These options either produce another source of pollution or increase the oil recovery cost. Plant biomass is renewable resource that can be converted into useful materials and energy. Barley straw, an agricultural waste, was used as sorbent material. The present study examines the absorption capacity of raw barley straw for different petroleum products and water pick up. The investigate revealed that the capacity of fibers to remove crude oil from sea water was related to the surface properties of the fibers, concentration of the oil, size of the fiber, amount of the fibers, as well as the temperature of the crude oil. Cyclic sorption / desorption studies indicated that a simple squeezing operation was enough to remove most of the oil sorbed and that recycling was feasible.
\end{abstract}

Key words: Oil recovery, natural sorbent, sorption, fiber

\section{INTRODUCTION}

Oil is one of the most important energy and raw material source for synthetic polymers and chemicals world wide (Annunciado et al.,2005). As long as oil is explored, transported, stored and used, there will be the risk of a spillage. Oil pollution, particularly of sea and navigable waters, has excited more public concern than other waste or spilt materials. Oil pollution of the sea has steadily increased with the increased oil consumption. The total annual influx of petroleum hydrocarbons is about 10 million metric tons. The bulk of this influx is due to transportation related activities spill from tanker loading and uploading operations, pipeline rupture which may be due to industrial waste as leakage from engines, incorrect operation of valves and discharge of oily wastes. Oil pollution of the shore, in addition to the reduction of amenity, also affects marine, shore life and vegetation. (Wardley Smith, 1983) Crude oil consists of different hydrocarbons that range

*Corresponding Author Email: maghrabyazza@yahoo.com Tel.: +2001 0308 7123; Fax: +2034 593423 from a light gas to heavy solids. When oil is spilled on water, the physical and chemical properties of oil change progressively, i.e. these physico-chemical changes enhance oil dissolution in seawater (Payne and Phillips, 1985). This process is referred to as weathering which includes evaporation, dissolution, dispersion, photochemical oxidation, microbial degradation, adsorption onto suspended materials, agglomeration, etc. (Jordan and Payne, 1980). Spilled oil has an undesirable taste and odor and causes severe environmental damage on water fowl, material life and affects tourism and economy (Kingston, 2002). Thus, various processes have been developed to remove oil from contaminated areas by use of booms, dispersants and skimmers, oil water separator or by use of different kinds of sorbent material (Nahla, 2008). The main limitations of some of these techniques are their high cost and inefficient trace level adsorption (Wei et al., 2005). Oil sorbents material can be categorized into three major classes: Inorganic mineral products, organic 
synthetic products and organic vegetable products (Wardley-Smith, 1983). Among synthetic sorbents which can be utilized, polypropylene nonwoven sorbents have high oil sorption capacity and low water uptake and thus, polypropylene nonwoven sorbents are ideal materials for oil recovery from the water surface. Previous studies show that mechanical recovery is the transfer of oil from the spilled area to some transportable form of temporary storage by the help of oil sorbents or skimmers (Choi and Moreau, 1992). It is recently reviewed that the porous materials used for oil spill cleanup and several studies of different natural, synthetic and mineral sorbents have also been conducted (Choi et al., 1993; Reynolds et al., 2001; Toyoda and Inagaki, 2003) producing a loose fibrous material which is oleophilic, hydrophobic and flootable on water for selective absorption of hydrocarbons (Preus, 1974). Most commonly used commercial sorbents are synthetic sorbents made of polypropylene or polyurethane (Teas et al., 2001). They have good hydrophobic and oleophilic properties, but their nonbiodegradability is a major disadvantage (Choi and Cloud, 1992; Deschamps et al., 2003). A biodegradable material with excellent absorption properties would be advantageous in this respect. A number of natural sorbents have been studied for use in oil-spill cleanup, e.g. cotton (Johnson et al., 1973; Choi and Kwon 1993; Choi, 1996), wool (Radetic et al., 2003) and bark (Haussard et al., 2003) which can be excellent oil sorbent because of its hydrophobic and oliophilic character. Baltrenas and Vaisis, 2005 studied the thermal modification influence on sorption qualities of biosorbents. Cellulosic sorbent has been chemically treated. Sugarcane bagasse was esterified with acetic anhydride using N-bromosuccinimide as a catalyst under mild conditions (Sun et al., 2004). The acetylation significantly increased hydrophobic properties of the bagasse and the oil sorption capacity of the acetylated bagasse obtained at $80^{\circ} \mathrm{C}$ for $6 \mathrm{~h}$ was 1.9 times than the commercial synthetic sorbents. Adebajo and Frost, (2004) studied the acetylation of cotton in order to develop hydrophobic, biodegradable cellulosic materials for subsequent application in oil spill cleanup. Finally, Edyta et al. (2003) concluded that the contact angle of oil on wet fresh straw for the external surface of the stalk and leaf is above $150^{\circ}$ which indicates that these surfaces are oleophilic in an aqueous environment. The objective of this research was to evaluate the possibility of removing weathered oil spilled on seawater using natural sorbents which is biodegradable using barley straw fiber produced in Egypt more than 300,000 feddans in the north west coast (NWC) and about 50,000 feddans in north Sinai (NS). The research was carried out in Faculty of Engineering, Alexandria, in April 2007. The sorption was carried out in simulated seawater bath containing crude oil to examine the feasibility of using these sorbents in oil spill clean up across different factors. The aim of studying the different factors for natural sorbent was to reach the suitable conditions for high sorption value.

\section{MATERIALS AND METHODS}

Sorbent material (Egyptian barley straw)

The barley straw was obtained from available local sources. It was thoroughly washed with water to remove dust, fungs and other foreign materials dried in sun light after that dried at $80^{\circ} \mathrm{C}$ for $2 \mathrm{~h}$ to insure complete removal of water and then crushed in Willey mill crusher and sieved to be used with different sizes (63, 125, 250, 500, 1000 and $2000 \mu \mathrm{m})$.

\section{Oil samples}

The oil (Marine Balaiem crude oil) used through all experiments from Alex Petroleum Company has specific gravity at $60 / 60$ (ASTM, 1998) equal 0.8780, API gravity 29.66 and viscosity $17.18 \mathrm{Cs}$ while for gas oil (from petroleum station) has density at $15^{\circ} \mathrm{C}=0.82$ $\mathrm{g} / \mathrm{cm}^{3}$ and viscosity 4.8 Cs. Crude oil contains low boiling fractions evaporated rapidly after a spill and often before significant cleanup operations can begin, in early stages of an oil spill, lighter hydrocarbons evaporate and consequently the oil viscosity increase before any possible cleanup operation can take place (Satish, 2003). Thus, in order to simulate this situation of oil spill and to minimize experimental variation (sorption procedure), the crude oils were held in thin layers in trays for one and seven days in open air. In the case of one days weathered oil (1 DWO), this treatment causes a weight loss of $21.78 \%$ while for seven days weathered oil (7 DWO) it was $47.47 \%$.

\section{Methods}

The primary considerations in the design of the procedure were a simultaneous contacting. A $500 \mathrm{~mL}$ of artificial sea water $(3.5 \% \mathrm{NaCl})$ was placed in a $1 \mathrm{~L}$ glass container (cell). $40 \mathrm{~g}$ of oil was added to the beaker container. One gram of sorbent was spread over the surface 
of the system. The beaker containing the oil sample and the artificial sea water was mounted in a shaker which was shaken for $15 \mathrm{~min}$ at 105 cycle $/ \mathrm{min}$. The bath temperature was kept constant at $25 \pm 1^{\circ} \mathrm{C}$ using thermostatic water bath. After $15 \mathrm{~min}$, the fibers (sorbent) were moved vertically with net and the sorbent was let to drain by hanging the net over the cell $5 \mathrm{~min}$. The sample weight was determined and recorded. During the pressing stage, a small amount of petroleum ether $(10-20 \mathrm{~mL})$ was added to the press to help extract the oil in fiber. The liquid was collected in a graduated centrifuge tube, the centrifuge tubes were put in water bath at $60^{\circ} \mathrm{C}$ for 20 -30 min to break any emulsion present (EPS 4 SP 3, 1991). The water content was determined by the centrifuge technique described in ASTMD4007-81 (ASTM, 1998). The amount of oil sorbed by the sorbent was determined by subtracting the water content and the initial sorbent weight from the total weight of the wetted sorbent.

Oil quantity sorbed is defined as follow:

$\mathrm{S}_{\mathrm{T}}-\mathrm{S}_{\mathrm{W}}-\mathrm{S}_{\mathrm{A}}$

Where, $\mathrm{S}_{\mathrm{T}}$ is the total weight ( $\mathrm{g}$ ) of oil water and sorbent material as determined gravimetrically, $\mathrm{S}_{\mathrm{w}}$ is the water weight (g), as determined by centrifugation and $S_{A}$ is the sorbent material weight (g). The quantity of oil was recorded as grams per gram sorbent.

\section{RESULTS AND DISCUSSION}

\section{Effect of particle size}

From reviewing a plot of data in Fig. 1, it is clearly observed that the oil absorbing function is improved with increased particle size (63- $2000 \mu \mathrm{m})$. Particles which do not pass through a mesh with a size of $250 \mu \mathrm{m}$ were found to be removed in the highest value in absorbing oil compared to particles which pass through a mesh size of 125, 63,500 and $2000 \mu \mathrm{m}$. The decrease in oil sorption capacity with decreasing particle size due to accumulation of small particles on each others which result in plugging pores and capillaries exists between fibers and the reverse decrease after $250 \mu \mathrm{m}$ may be due to decrease of the surface area subjected to oil bath. The very low sorption capacity of the barley for water may be due to hydrophobic property of barley straw resulted from the wax layer leaves and steams of barley which repellent the water (Amer et al., 2007).

\section{Effect of sorption time}

Fig. 2 shows the results of sorption times (5- $30 \mathrm{~min}$ ) on oil removal and as expected, sorption capacity increases with the sorption period from 5 to $30 \mathrm{~min}$. Sorption capacity followed the trend of 7 DWO $>1$ DWO > gas oil according to difference in viscosity while maximum value was at 15 min for $1 \mathrm{DWO}$ and 7 DWO which may be due to adsorption on first surface and then start to penetrate the inner microscopic voids (Amer et al.,2007). After that, for $1 \mathrm{DWO}$ the value is approximately constant and decreases for 7 DWO. For gas oil, the maximum value of sorption was at $10 \mathrm{~min}$ and then decreased with increasing sorption time. Also, the figure shows that the amount of sorbed water increases with increase in sorption time.

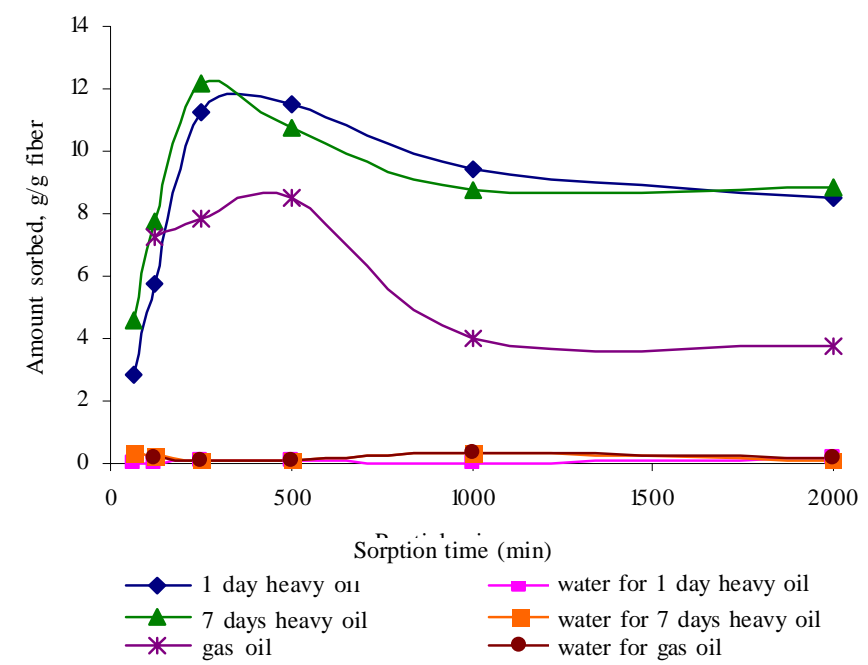

Fig. 1: Effect of particle size on oil sorption capacity and water pick up 


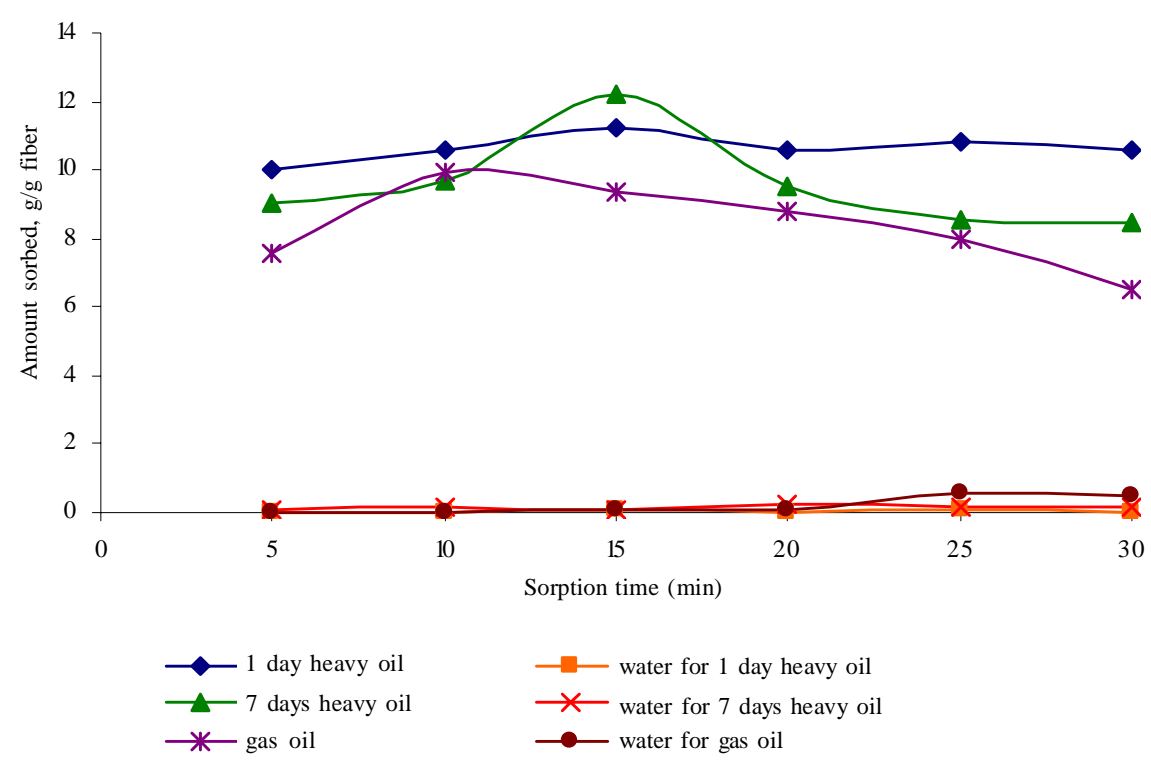

Fig. 2: Effect of sorption time on oil sorption capacity and water pick up

\section{Oil sorption and retention}

The results shown in Fig. 3 indicate that the oil sorption and retention properties vary for different oil viscosities. The oil with higher viscosity (7 DWO) tends to have higher initial sorption ratio. The high viscosity of heavy oil significantly affects the capillary penetration of oil into the small pores of sorbent material (Fig. 4). The results show that the retention behavior of all used oil follows almost the same trend. As shown, there are three zones in each curve: The first zone is the initial stage of release which occurs over the first min and the rate of release is very high during this period; the second or transition zone occurs from 1 to 5 min over this period which in the rate of release is reduced and the third zone represents the steady state period during this period and additional time will not release any significant amount of oil (Garg et al., 2004). Light oil tends to be released from sorbent fast with high release rate compared to the heavy oil. Thus, the curve has only two zones. These results are in agreement with those reported by Choi et al., (1993) who studied the sorption desorption on cotton nonwoven fibers.

\section{Effect of oil film thickness}

The amount of oil adsorbed as a function of film thickness (1-5 mm thickness) is shown in Fig. (5) with adsorbent dosage of $1.0 \mathrm{~g}$. Data shows increasing oil sorption capacity with increasing the oil film thickness. The high value of sorption is for seven days weathered oil followed by 1 DWO and lowest values for gas oil. This may be due to the difference in viscosity. At the same time that the film thickness increases, the water pick up decreases to reach nearly zero value which maybe due to increase in oil film thickness which nearly isolates the sorbent than water except the interference due to artificial waves.

\section{Effect of sorbent dosage}

The interaction between the oil and the sorbent could be affected by the sorbent dosage. The results shown in Fig. 6 reveal the effect of sorbent dosage varied from 0.25 to $3 \mathrm{~g}$ of sorbent for one and seven days weathered Marine Balaiem crude oil also for gas oil. Increasing sorbent weight increases the sorption capacity. Also, for one day oil the sorption capacity continues to increase with increase weight while for seven days oil, the sorption value is nearly constant for 2 and $3 \mathrm{~g}$ sorbent which may be due to the difference in viscosity, but for gas oil, the sorbed amount of oil increases with increasing the sorbent weight and the amount of water also increased and this may be due to lower viscosity of gas oil, i.e. with increasing amount of sorbent, it removes large amount of oil. Thus, the interface between oil and water nearly disappeared allowing sorbent to absorb high value of water. 


\section{Effect of temperature}

Fig. 7 shows the effect of temperature on oil removal. It can be seen that the oil sorption capacity increases with increasing temperature. This increase may be due to the decrease in the oil viscosity at higher temperature to be suitable to penetrate pores and rest between surface roughness until reach maximum value of oil sorption at $25^{\circ} \mathrm{C}$. Meanwhile, at lower temperatures, the high oil viscosity may plug pores and obstacle oil to penetrate and increasing temperature than $25^{\circ} \mathrm{C}$ starts to decrease when oil starts to be very light which leads to release oil from fibers again (Hyung and Kwan, 1993; Namasivayam and Arasi, 1997). Choi et al., (1993) and Johnson et al., (1973) agree about these results.

\section{Effect of oil type}

Different types of oil were studied such as Marine Balaiem, Western Desert crude oil, Russian oil and finally, Arabia heavy crude oil which have significant effects on the oil removal from the used sorbent. The increase in oil viscosity caused considerable decrease in oil removal.

\section{Effect of reusability}

In a practical oil spill clean up operation on the water, oil is removed from the sorbent by simple mechanical action and the sorbent is reapplied several times. Fig. 8 illustrates that oil sorption capacity decreases during repeated use. For 1 DWO, the oil sorption value was $11 \mathrm{~g} / \mathrm{g}$ fiber which decreases to nearly $6.5 \mathrm{~g} / \mathrm{g}$ fiber in the second use and can be referred to the irreversible deformation of the barley straw due to tearing, crushing or other general deterioration during squeezing. The same recycling performance was observed for seven days oil while in the first time, the sorbed amount is nearly $12 \mathrm{~g} / \mathrm{g}$ fiber and after recycling for the first time,
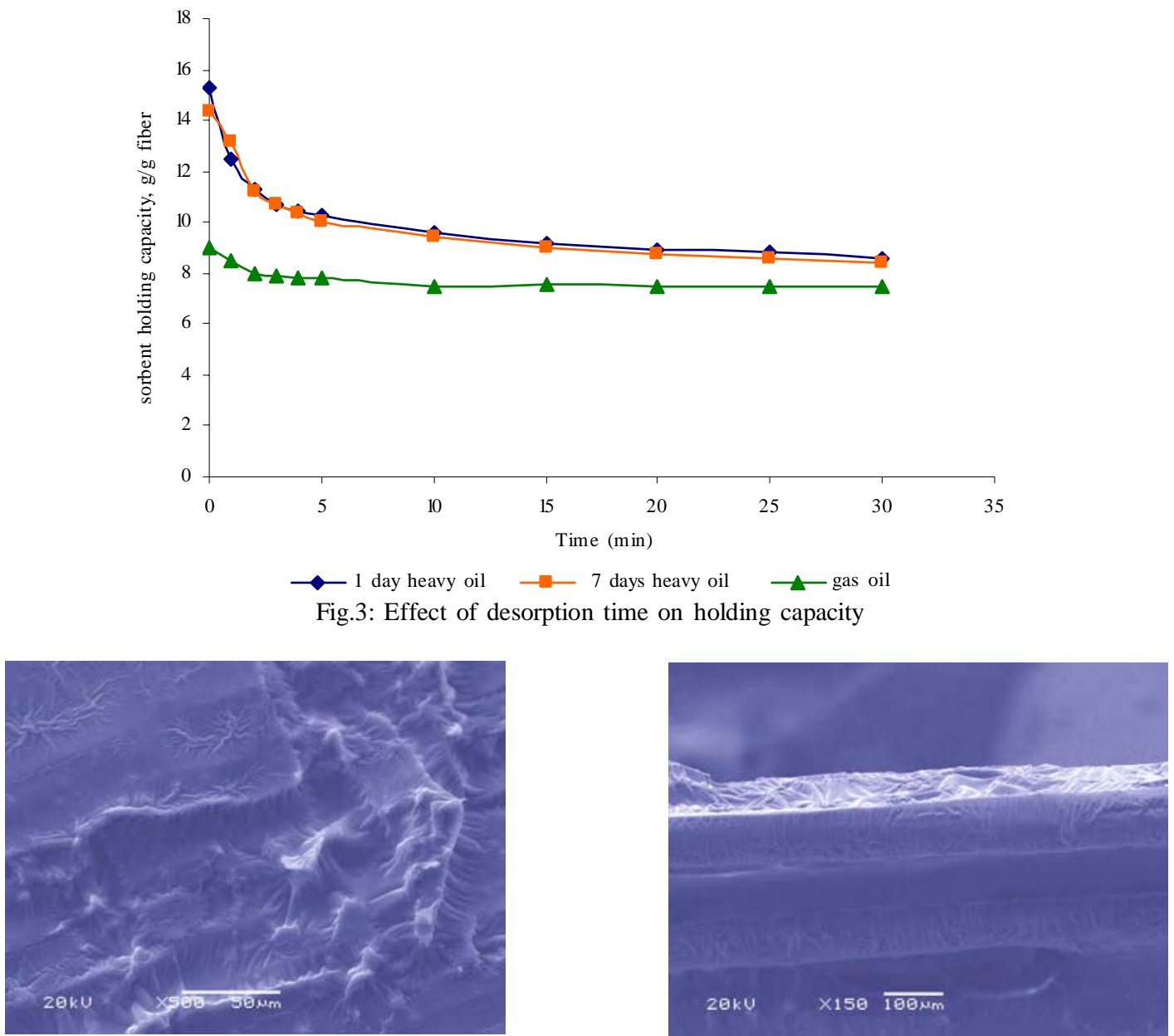

Fig. 4: SEM for surface and thickness of barley straw after heavy oil sorption with magnification factor 500 


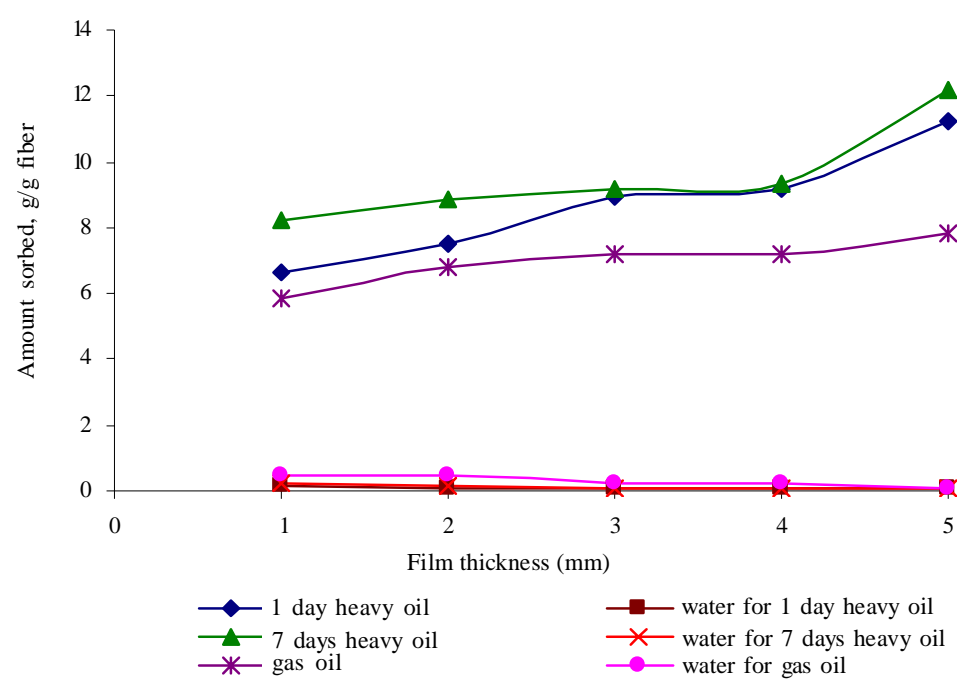

Fig. 5: Effect of oil film thickness on oil sorption capacity and water pick up

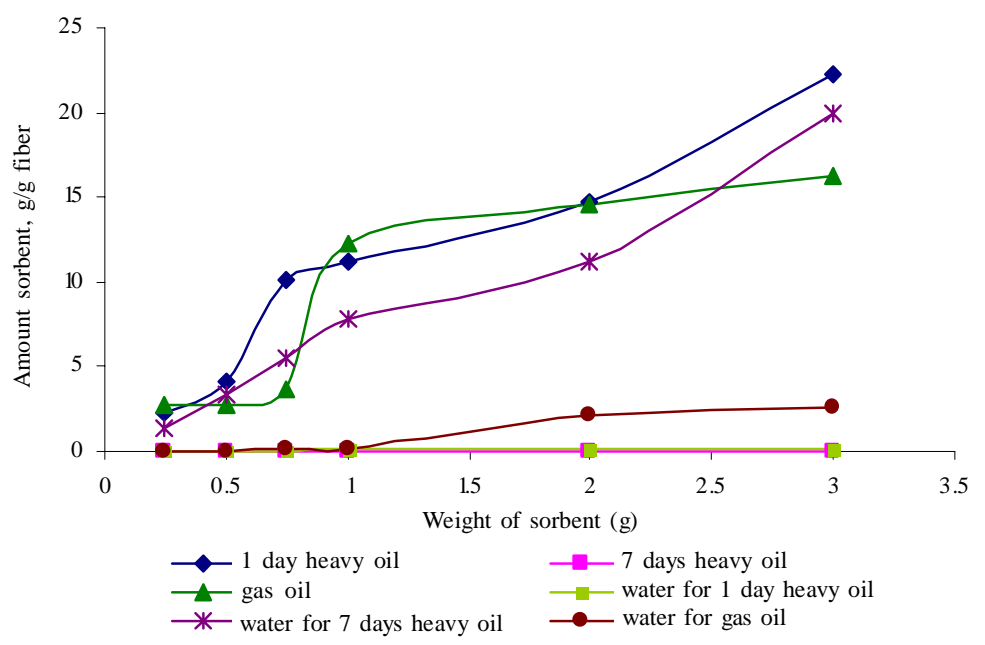

Fig. 6: Effect of sorbent weight on oil sorption capacity and water pick up

the value equals $7 \mathrm{~g} / \mathrm{g}$ fiber. Also, the same behavior is for gas oil, i.e. the amount sorbed at the first time is 7.8 $\mathrm{g} / \mathrm{g}$ fiber and $5 \mathrm{~g} / \mathrm{g}$. This decrease could be attributed to the disruption of the fibers by mechanical action.

\section{CONCLUSION}

The oil sorption capacity was found to be dependent on the sorption time and the system condition such as oil temperature and film thickness. The sorbed oil was removed from sorbent by a simple mechanical press suggesting the reusing the sorbent for several times. The results showed the maximum values of sorption capacity at 11.23 (1 DWO), 12.2 (7 DWO) and 7.8 for gas oil at $250 \mu \mathrm{m}$ particle size, 15 min sorption time, 5 min dripping time, film thickness of $5 \mathrm{~mm}$ at temperature $25^{\circ} \mathrm{C}$. Also, the amount of water pick up was small due to wax layer covering the barley straw tissue. Finally, it can be reused 3 times to reach $50 \%$ of the first sorption value. The results suggest that substitution of commercial synthetic oil sorbents in oil spill clean up is possible by agriculture residue and could be beneficial by incorporating other advantages such as biodegradability. 


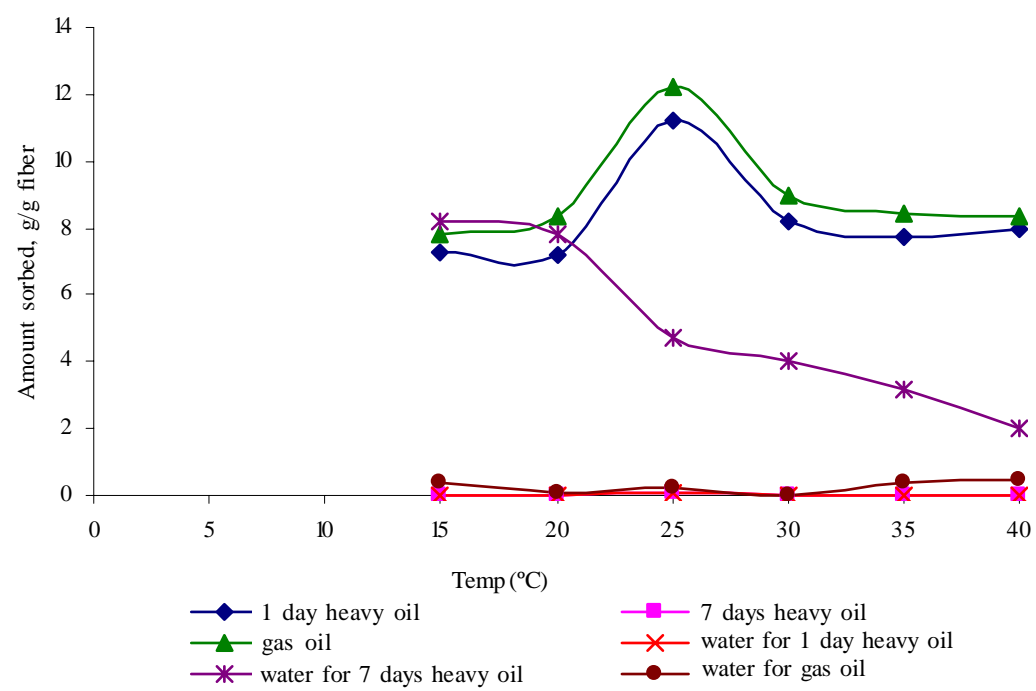

Fig. 7: Temperature effect on oil sorption capacity and water pick up

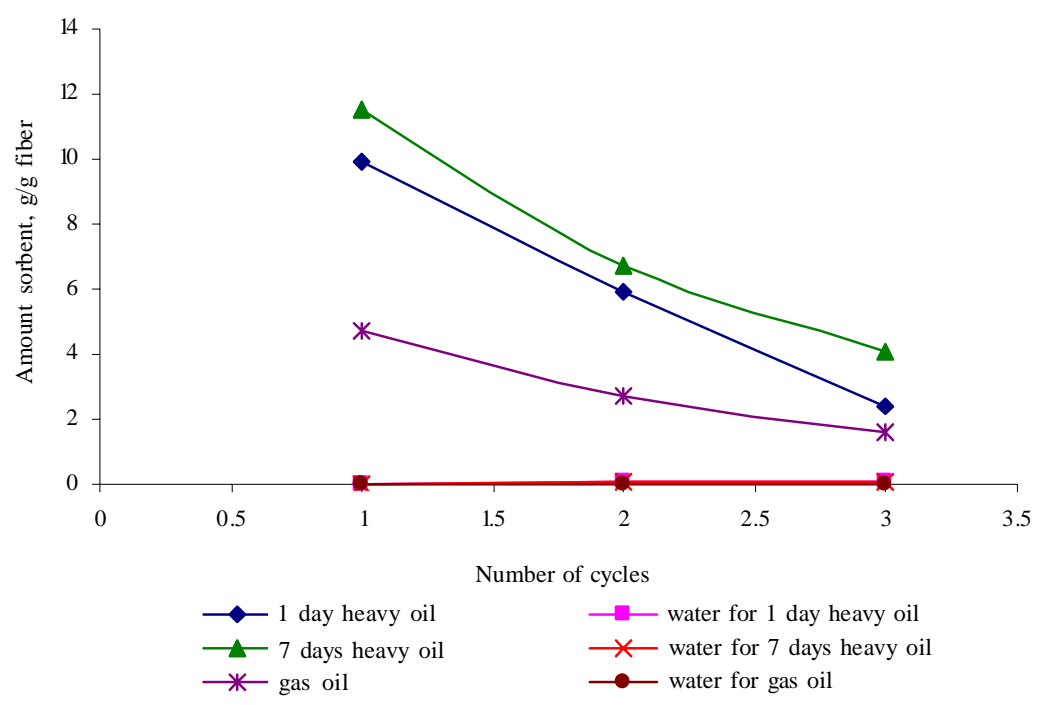

Fig. 8: Reusability of sorbent on oil sorption capacity and water pick up

\section{REFERENCES}

Adebajo, M. O.; Forest, R. L., (2004). Infrared and C MADS nuclear magnetic resonance spectroscopic study of acetylation of cotton., Spectrochim. Acta. A, 60 (1), 449453.

Amer, A. A.; El Maghraby, A.; Malash, G. F.; Nahla. T. A., (2007). Extensive characterization of raw barley straw and study the effect of steam pretreatment, J. Appl. Sci. Res. 3 (11), 1336-1342.

ASTM, (1998). D4007-81: Standard test method for water and sediment in crude oil by the centrifuge method, in: Annual book of American society for testing and materials standards. ASTM committee on standards, West Conshohocken, PA.

Annunciado, T. R.; Sydenstricker, T. H. D.; Amico, S. C., (2005). Experimental investigation of various vegetable fibers as sorbent materials for oil spills., Mar. Pollut. Bull., 50 (11), 1340-1346.

Balternas, P.; Vaisis, V., (2005). Experimental investigation of thermal modification influence on sorption qualities of biosorbents., Environ. Eng. Landscape Manage. 13 (1), 3-8.

Choi, H.; Cloud, R. M., (1992). Natural sorbents in oil spill cleanup., Environ. Sci. Tech., 26 (4), 772-776. 
Choi, H. M.; Kwon, H.; Moreau, J., (1993). Cotton nonwovens as oil spill clean up sorbents., Text. Res. J., 63 (4), 211-218.

Choi, H. M., (1996). Needle punched cotton nonwoven and other natural fibers as oil clean up sorbents., Environ. Sci. Health, A, (31), 1441-1457.

Deschamps, G.; Caruel, H.; Borredon, M. E.; Bonnin, C.; Vignoles, C., (2003). Oil removal from water by selective sorption on hydrophobic cotton fibers. 1. Study of sorption properties and comparison with other cotton fiber-based sorbents., Environ. Sci. Tech., 37 (5), 1013-1015.

Edyta, W. J.; Jan, H.; Piotr, P., (2003). Investigation of oleophilic nature of straw sorbent conditioned in water., Spill Sci. Tech. B., 8 (5-6), 561-564.

Environment Canada, (1991). Selection criteria and laboratory evaluation of oil spill sorbent, up data IV, Environment Canada, Report EPS 3-SP-3, Ottawa.

Garg, V. K.; Moirangthem, A.; Kumar, R.; Gupta, R., (2004). Basic dye (methylene blue) removal from simulated wastewater by adsorption using Indian rosewood sawdust: Timer industry waste., Dyes Pigents, 63 (3), 243-250.

Haussard, M.; Gaballah, I.; Kanari, N.; de Donato, P.; Barre's, O.; Villieras, F., (2003). Separation of hydrocarbons and lipid from water using treated bark., Water Res., 37 (2), 362-374.

Hyung, M. C.; Kwon, H. J., (1993). Cotton nonwovens as oil spill cleanup sorbents., Text. Res. J., 63 (4), 211-218.

Johnson, R.; Manjrekar, T.; Halligan, J., (1973). Removal of oil from water surfaces by sorption on unstructured fibers., Environ. Sci. Tech., 7 (5), 439- 443.

Jordan, R. E.; Payne, J. R., (1980). Fate and weathering of petroleum spills in the marine environment: A literature review and synopsis. Ann Arbor science publishers, Ann Arbor, MI, USA.

Kingston, P. F., (2002). Long-term environmental impact of oil spills., Spill Sci. Tech. B., 7 (1-2), 53-61.

Nahla A. T., (2008). Study on the use of barley straw for oil spill cleanup, A thesis presented to graduate school, Faculty of Engineering, Alexandria University.
Namasivayam, C.; Arasi, J. S. E., (1997). Removal of congo red from wastewater by adsorption onto waste red mud., Chemosphere, 34 (2), 401-417.

Payne, J. R.; Phillips, C. R., (1985). Photochemistry of petroleum., Environ. Sci. Tech., 19 (7), 569-579.

Preus, P., (1974). Perlite-asphalt-fiber compositions for separating hydrocarbon from water. US Planet., 3855152.

Radetic, M.; Jocic, D.; Jovancic, P.; Petrovic, Z.; Thomas, H., (2003). Recycled wool-based nonwoven material as an oil sorbent., Environ. Sci. Tech. 37 (5), 1008-1012.

Reynolds, J. G.; Coronado, P. R.; Hrubesh, L. W., (2001). Hydrophobic aerogels for oil-spill cleanup-intrinsic absorbing properties., Energ. Source., 23 (9), 831-843.

Rowell, R. M.; Stout, H. P., (1998). Chapter 7: Jute and Kenaf, in: Lewin, M.; Pearce, E. M., (Eds.), Handbook of Fiber Chemistry, second Ed. Marcel Dekker., Inc., New York, 465- 504.

Satish, M. M., (2003). Vallabh Vidyanagar, India; Sãdhanã 28 $(1-2), 335-348$.

Sun, X. F.; Sun, R. C.; Sun, J. X., (2004). Acetylation of sugarcane bagasse using NBS as acatalyst under mild reaction conditions for the production of oil sorption-active materials., Bioresource Tech. 95 (3), 343-350.

Teas, C.; Kalligeros, S.; Zanikos, F.; Stournas, S.; Lois, E.; Anastopoulos, G., (2001). Investigation of the effectiveness of absorbent materials in oil spills clean up., Desalination, 140 (3), 259-264.

Toyoda, M.; Inagaki, M., (2003). Sorption and recovery of heavy oils by using exfoliated graphite., Spill Sci. Tech. B., 8 (2), 467- 474.

Wardley Smith, J., (1983). The control of oil pollution. Graham and Trotman Publication, London.

Wei, Q. F.; Mather, R. R; Fotheringham, A. F., (2005). Oil removal from used sorbents using a biosurfactant, Bioresource Tech., 96 (3), 331-334.

\section{AUTHOR (S) BIOSKETCHES}

Hussein, M., Professor, Alexandria University, Faculty of Engineering, Chemical Department, Alexandria, Egypt. Email: mhusseina@hotmail.com

Amer, A. A., Professor, Alexandria Petroleum Company, Alexandria, Egypt. Email: amer_abdelrazik@yahoo.com

El-Maghraby, A., Ph.D., Department of Fabrication Technology, Institute of Advanced Technology and New Materials, Mubarak City for Scientific Research and Technology Applications, Alexandria, Egypt.

Email:maghrabyazza@yahoo.com

Taha, N. A., M.Sc., Institute of Advanced Technology and New Materials, Mubarak City for Scientific Research and Technology Applications, Alexandria, Egypt. Email: nahlataha_1982@yahoo.com

This article should be referenced as follows:

Hussein, M.; Amer A. A.; El-Maghraby, A.; Taha, N. A., (2008). Study the availability of using barley straw for oil spill clean up. Int. J. Environ. Sci. Tech., 6 (1), 123-130. 